\title{
Synthesis and Structural Characterization of a New Two-Dimensional Polymeric Hybrid Material $\left\{\left[\mathrm{Cu}_{3}\left(\mu_{3}-1,2,3-\mathrm{BTC}\right)\left(\mu_{2}-1,2,3-\mathrm{BTC}\right)\right.\right.$ $\left.\left.(\mathrm{en})_{3}\left(\mathrm{OH}_{2}\right)_{2}(\mathrm{OH})\left(\mu_{2}-\mathrm{OH}_{2}\right)\right]_{2} \cdot 5 \mathrm{H}_{2} \mathrm{O} \cdot 0\right\}_{\mathrm{n}}$
}

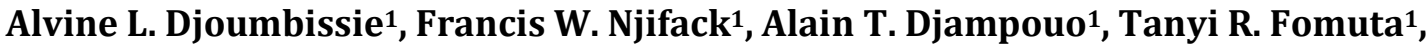 \\ Golngar Djimassingar ${ }^{2}$, Alain C. Tagne Kuate ${ }^{1^{*}}{ }^{\mathbb{C}}$, Jean Ngoune $^{1^{*}}$ \\ ${ }^{1}$ Department of Chemistry, Faculty of Science, University of Dschang, Dschang, Cameroon \\ ${ }^{2}$ Department of Chemistry, Mongo Polytechnique University Institute (IUPM), Mongo, Chad \\ Email: *jeangoune@yahoo.com, *alctagne@gmail.com
}

How to cite this paper: Djoumbissie, A.L., Njifack, F.W., Djampouo, A.T., Fomuta, T.R., Djimassingar, G., Kuate, A.C.T. and Ngoune, J. (2020) Synthesis and Structural Characterization of a New Two-Dimensional Polymeric Hybrid Material

$\left\{\left[\mathrm{Cu}_{3}\left(\mu_{3}-1,2,3-\mathrm{BTC}\right)\left(\mu_{2}-1,2,3-\mathrm{BTC}\right)\right.\right.$

(en $\left.\left.)_{3}\left(\mathrm{OH}_{2}\right)_{2}(\mathrm{OH})\left(\mu_{2}-\mathrm{OH}_{2}\right)\right]_{2} \cdot 5 \mathrm{H}_{2} \mathrm{O} \cdot \mathrm{O}\right\}_{\mathrm{n}}$.

Open Journal of Inorganic Chemistry, 10,

52-62.

https://doi.org/10.4236/ojic.2020.104006

Received: June 8, 2020

Accepted: September 16, 2020

Published: October 19, 2020

Copyright $\odot 2020$ by author(s) and Scientific Research Publishing Inc. This work is licensed under the Creative Commons Attribution International License (CC BY 4.0).

http://creativecommons.org/licenses/by/4.0/ (c) (i) Open Access

\section{Abstract}

The reaction of benzene-1,2,3-tricarboxylate copper(II) trihydrate $\left(\mathrm{Cu}_{3}(1,2,3-\mathrm{BTC})_{2} \cdot 3 \mathrm{H}_{2} \mathrm{O}\right)$ and ethylenediamine (en) gave after recrystallization from methanol at room temperature violet crystalline solid of the polymeric two dimensional material

$\left\{\left[\mathrm{Cu}_{3}\left(\mu_{3}-1,2,3-\mathrm{BTC}\right)\left(\mu_{2}-1,2,3-\mathrm{BTC}\right)(\mathrm{en})_{3}\left(\mathrm{OH}_{2}\right)_{2}(\mathrm{OH})\left(\mu_{2}-\mathrm{OH}_{2}\right)\right]_{2} \cdot 5 \mathrm{H}_{2} \mathrm{O} \cdot \mathrm{O}\right\}_{\mathrm{n}} \quad$ (1) as identified by single crystal $\mathrm{X}$-ray diffraction analysis. The compound was also characterized by elemental analysis, FT-IR spectroscopy, UV-vis spectroscopy, thermogravimetric analysis (TGA) and magnetic susceptibility. The molecular structure indicates crystallization in the triclinic space group P-1 with the unit cell parameters $\mathrm{a}=12.1205(3) \AA, \mathrm{b}=12.7026(3) \AA$, c $=13.9890$ (3) $\AA, \alpha=75.034(1)^{\circ}, \beta=74.957(1)^{\circ}, \gamma=68.415(1)^{\circ}$. Structural analysis also revealed that the dimeric compound is connected by $\mathrm{Cu}-\mathrm{O}-\mathrm{Cu}$ bridges and the dimer is further converted into a polymeric chain structure through bridging of one benzene-1,2,3-tricarboxylate ligand. Different coordination modes are observed at the copper atom. The $\mathrm{Cu}$ atom at the center is octahedral while the two other ones are pentacoordinated. Thermal analysis of the compound showed decomposition processes, while magnetic studies indicated a magnetic susceptibility $\mu$ of $3.21 \mathrm{BM}$.

\section{Keywords}

Copper, Ethylenediamine, Benzene-1,2,3-Tricarboxylate, Coordination Polymer, Magnetism 


\section{Introduction}

Polyfunctional hybrid organo-inorganic materials such as metal-organic frameworks (MOFs), microporous organic materials (MOMs) and coordination polymers (CPs) continue to be of great interest for the scientific community owing to their structural and unusual properties as compared with those of activated carbon, silica gel and zeolite [1]. Attractions to this class of materials result not only from the several advantages associated with their intrinsic structural characteristics, but also from their rich physico-chemical properties with potential applications in gas storage, molecular recognition and separation of substrates, and in heterogeneous catalysis [2] [3] [4]. Gas storage is of critical importance in many industrial processes both from an economic and safety point of view. For instance, metal carboxylates such as $\left[\mathrm{Cu}_{2}(\mathrm{pzdc})_{2}(\mathrm{pyz})\right]$ (where pzdc ${ }^{2-}=$ pyrazine-2,3-dicarboxylate, pyz $=$ Pyrazine $)$ and $\left[\mathrm{Cu}_{3}(\mathrm{BTC})_{2}\right]\left(\mathrm{BTC}^{3-}=\right.$ benzene-1,3,5tricarboxylate), characterized by pores radius of $4 \times 6 \AA$ and $12 \times 12 \AA$, respectively, are well suitable for acetylene and $\mathrm{CO}_{2}$ adsorption [5] [6]. These abilities of MOFs, MOMs, and CPs to store gases such as methane, ethylene, dihydrogen, carbon dioxide or dinitrogen have led to the replacement of compressed natural gas (CNG) by adsorbed natural gas (ANG), which therefore represents an alternative source of energy in the production of fuels [7].

Continuous research works on materials able to favor gas storage by adsorption are then expected to provide a great contribution in the mitigation of environmental pollution and global warming. In that respect, metal di- or tricarboxylates in association with bidentate amines represent excellent precursors for the generation of coordination polymers that hold potential as inorganic material in the adsorption of small molecules. Some recent examples include the synthesis of 3D- $\left\{\left[\mathrm{Cu}\left(\mathrm{NCCH}_{3}\right)_{4}\right]\left[\mathrm{Cu}_{3}\left(\mu_{6} \text {-btc }\right)_{2}\right]_{2}\left(\mathrm{O}_{2} \mathrm{CCH}_{3}\right)\left(\mathrm{H}_{2} \mathrm{O}, \mathrm{CH}_{3} \mathrm{CN}\right)_{\mathrm{x}}(\text { btrip })_{1.5}\right\}_{\mathrm{n}}$ from 1,2-bis(1,2,4-triazol-4-yl)propane, in combination with benzene-1,3,5-tricarboxylate [8].

We recently investigated the reaction of several diamine precursors such as 1,3-diaminepropane (tn) with $\mathrm{Cu}(\mathrm{NDC}) \cdot 3 \mathrm{H}_{2} \mathrm{O}\left(\mathrm{NDC}^{2-}=\right.$ naphthalenedicarboxylate) and isolated the complex $\left\{\left[\mathrm{Cu}(\mathrm{NDC})\left(\mathrm{OH}_{2}\right)\left(\mu-\mathrm{OH}_{2}\right)(\mathrm{tn})\right]_{\mathrm{n}} \cdot 2 \mathrm{H}_{2} \mathrm{O}\right\}$ that has been characterized in the solid state by single crystal $\mathrm{X}$-ray diffraction analysis. Its molecular structure revealed a $2 \mathrm{D}$ coordination polymer in which the monomeric units are associated by intermolecular hydrogen bonding interactions [9]. In the continuation of this work, we report here the synthesis and structural characterization of a novel CPs based on benzene-1,2,3-tricarboxylatecopper(II) trihydrate $\left(\mathrm{Cu}_{3}(1,2,3-\mathrm{BTC})_{2} \cdot 3 \mathrm{H}_{2} \mathrm{O}\right)$ and ethylenediamine (en) with the former as primary building unit.

\section{Experimental}

\subsection{Materials and Methods}

All chemicals were purchased from commercial sources and used as received without further purification. Benzene-1,2,3-tricarboxylatecopper(II) trihydrate 
was of analytical grade. Elemental analysis was performed using a Fisons Instruments 1108 CHNS-O analyzer. FT-IR spectra were recorded using a Perkin-Elmer FT-IR 100 spectrometer. UV-visible measurements were carried out by the aid of a Jenway $6715 \mathrm{UV}$-vis spectrophotometer. The melting point of the compound was obtained using an SMP3 Stuart Scientific Melting Point Apparatus while thermogravimetric analysis was carried out using a Perkin-Elmer STA 6000 thermobalance. Magnetic susceptibility was carried out using a Gouy magnetic balance. Reflections were collected on a Bruker SMART APEX II CCD Diffractometer using CuK $\alpha(1.54178 \AA$ ) radiation at $100 \mathrm{~K}$. Dataprocessing, Lorentz-polarization, and face-indexed numerical absorption corrections were performed using SAINT, APEX, and SADABS computer programs [10] [11] [12]. The structures were solved by direct methods and refined by full-matrix least squares based on F2 with all reflections using the SHELXTL V6.14 program package [13] [14]. Non-hydrogen atoms were refined with anisotropic displacement coefficients. All $\mathrm{H}$ atoms were found in electron-density difference maps and carbon-bound $\mathrm{H}$ atoms were treated as idealized contribution unless noted differently. Structural data have been deposited with the Cambridge Structure Database as supplementary publications CCDC 1990458.

\subsection{Synthesis of $\left\{\left[\mathrm{Cu}_{3}\left(\mu_{3}-1,2,3-\mathrm{BTC}\right)\left(\mu_{2}-1,2,3-\mathrm{BTC}\right)(\mathrm{en})_{3}\left(\mathrm{OH}_{2}\right)_{2}\right.\right.$ $\left.\left.(\mathrm{OH})\left(\mu_{2}-\mathrm{OH}_{2}\right)\right]_{2} \cdot 5 \mathrm{H}_{2} \mathrm{O} \cdot 0\right\}_{\mathrm{n}}(1)$}

A sky blue powder of benzene-1,2,3-tricarboxylatecopper(II) trihydrate (2.0 g, $3.0 \mathrm{mmol})$ was introduced in methanol $(25 \mathrm{~mL})$ and the mixture was stirred for $1 \mathrm{~h}$ at room temperature. To the blue solution obtained was added ethylenediamine $(0.56 \mathrm{~g}, 9.3 \mathrm{mmol})$, and the mixture was kept at room temperature under stirring for $24 \mathrm{~h}$, whereby a violet solid precipitated in the reaction flask. The solid was filtered off, washed several times with methanol and dried under air. Recrystallization from methanol by slow partial evaporation of the solvent afforded pure 1 as violet crystals. Yield $2.20 \mathrm{~g}(72 \%)$. Anal. Calcd. (\%) for $\mathrm{C}_{24} \mathrm{H}_{45} \mathrm{Cu}_{3} \mathrm{~N}_{6} \mathrm{O}_{21}$ : C 30.53, H 4.80; N, 8.90. Found (\%): C 30.34, H 4.97, N 8.76. FT-IR $\left(v, \mathrm{~cm}^{-1}\right)$ : $3496.0(\mathrm{~m}), 3400.8(\mathrm{~m}), 3107.0$ (s), 1595.5 (vs), 1558.9 (vs), 1451.3 (s), 1362.6 (vs), $1280.1(\mathrm{~m}), 1157.7(\mathrm{w}), 1122.5(\mathrm{w}), 1052.8(\mathrm{vs}), 927.4(\mathrm{w}), 768.5(\mathrm{~m}), 726.2$ (w), $704.4(\mathrm{~s}) \mathrm{cm}^{-1}$

\section{Results and Discussion}

\subsection{Synthetic Aspects}

Complex 1 was obtained by mixing benzene-1,2,3-tricarboxylatecopper(II) trihydrate, prepared from benwene-1,2,3-tricarboxyates and copper(II) chloride, with excess equivalent of ethylene diamine in methanol at room temperature. The crude product was recrystallized from methanol by slow evaporation and violet crystalline solid of $\mathbf{1}$ was isolated in good yield (Scheme 1).

Compound 1 displayed a violet color and showed some solubility in organic solvent such as methanol, dimethylformamide and acetonitrile. The material can be handled and stored at air for months without any sign of decomposition. 


$$
\begin{aligned}
& \text { 2n } \mathrm{Cu}_{3}(1,2,3-\mathrm{BTC}) 2 \cdot 3 \mathrm{H}_{2} \mathrm{O}+3 \mathrm{n} \mathrm{H}_{2} \mathrm{~N}_{-} \mathrm{C}_{2} \mathrm{H}_{4}-\mathrm{NH}_{2} \\
& \begin{array}{c|l}
\text { methanol } & \\
6 \mathrm{H}_{2} \mathrm{O} & \text { r.t., overnight } \\
0.5 \mathrm{O}_{2} & -0.5 \mathrm{H}_{2}
\end{array} \\
& \left\{\left[\mathrm{Cu}_{3}\left(\mu_{3}-1,2,3-\mathrm{BTC}\right)\left(\mu_{2}-1,2,3-\mathrm{BTC}\right)(\mathrm{en})_{3}\left(\mathrm{OH}_{2}\right)_{2}(\mathrm{OH})\left(\mu_{2}-\mathrm{OH}_{2}\right)\right]_{2} \cdot 5 \mathrm{H}_{2} \mathrm{O} \cdot \mathrm{O}\right\} \mathrm{n} \\
& 1
\end{aligned}
$$

Scheme 1. Synthesis of the two dimensional polymeric complex 1.

\subsection{Thermal Properties}

TGA (light red curve)/heat flow (dark red curve) profiles of 1 (Figure 1) showed processes with weight loss. The compound showed a $16 \%$ weight loss between $40^{\circ} \mathrm{C}-120^{\circ} \mathrm{C}$, which can be assigned to the departure of six water molecules (calc. $11.2 \%$ ) and one molecule of ethylene diamine (6.2\%). Above $200^{\circ} \mathrm{C}$, further decomposition of the compound occurs with a final weight loss of $32 \%$ at $243^{\circ} \mathrm{C}$ and corresponding to the departure of a benzene-1,2,3-tricarboxylic acid molecule (calc. 21.43\%) and two molecules of ethylenediamine (calc.12.4\%). These decompositions are supported by two endothermic effects at around $97^{\circ} \mathrm{C}$ and $210^{\circ} \mathrm{C}$.

\subsection{Magnetic Properties}

The magnetic properties of the polymeric complex 1 was evaluated by determining the effective magnetic moment $\mu_{\text {eff }}$ of the compound according to the formula $\mu_{\text {eff }}=2.828 \times\left(\chi_{\text {Mcor }} T\right)^{1 / 2}$, where $\chi_{\text {Mcor }}$ is the corrected molar susceptibility. Table 1 gives the diamagnetic contribution $\chi_{\mathrm{a}}$ of each atom or group of atoms in 1. The measured value $\chi_{\mathrm{g}}$ was found to be $0.437 \times 10^{-5}$ and the magnetic susceptibility $\chi_{\mathrm{M}}$ of the compound was calculated to be $0.437 \times 10^{-5} \times 1015.38=4377 \times$ $10^{-6}$.

The corrected magnetic susceptibility is $\chi_{\text {Mcor }}=\left(\chi_{\mathrm{M}}-\chi_{\mathrm{Dia}}\right)=4805 \times 10^{-6}$ and the effective magnetic moment was deduced to be $\mu_{\text {eff }}=2.828 \times\left(4805 \times 10^{-6} \times 292\right)^{1 / 2}=$ 4.0 BM. This value is close to that of a system with three free electrons $(s=3 / 2, \mu=$ $3.87 \mathrm{BM}$ ) and might suggest a spin-spin coupling that is antiferromagnetic. Ghoshal and coworkers observed antiferromagnetic coupling in the dicarboxylate copper complexes $\left[\mathrm{Cu}_{2}\left(\mu-\mathrm{OH}_{2}\right)_{2}\left(\mathrm{OOC}-\mathrm{CH}_{2} \mathrm{CH}_{2}-\mathrm{COO}\right)(\mathrm{bpy})_{2}\left(\mathrm{NO}_{3}\right)_{2}\right]_{\mathrm{n}}$ and $\left[\mathrm{Cu}_{2}\left(\mu-\mathrm{OH}_{2}\right)_{2}\right.$ (OOC- $\left.\left.\mathrm{CH}_{2} \mathrm{CH}_{2}-\mathrm{COO}\right)(\text { phen })_{2}\left(\mathrm{NO}_{3}\right)_{2}\right]_{\mathrm{n}}[15]$.

\subsection{IR Spectroscopy}

The FT-IR spectrum of 1 (Figure 2) showed that valence vibrations of $v_{\mathrm{as}}(\mathrm{N}-\mathrm{H})$, $v_{\mathrm{a}}(\mathrm{N}-\mathrm{H}), v(\mathrm{O}-\mathrm{H})$ occur almost in the same region, with a broad and intense absorption band observed at $3496-2800 \mathrm{~cm}^{-1}$. The vibration bands of $v(\mathrm{O}-\mathrm{H})$ at 3496 $\mathrm{cm}^{-1}$, expected at about $3500 \mathrm{~cm}^{-1}$, is slightly displaced towards lower frequencies, indicating that the proton is engaged in the hydrogen bonds with oxygen atoms of benzene-1,2,3-tricarboxylate. Similarly, the valence vibration of $\mathrm{N}-\mathrm{H}$ observed at $3107 \mathrm{~cm}^{-1}$, is slightly above the expected interval $3100-2850 \mathrm{~cm}^{-1}$. Similar displace- 
ments of $\mathrm{N}-\mathrm{H}$ stretching frequency due to hydrogen interactions were observed in the reported cadmium $\left[\mathrm{Cd}(\mathrm{OAc})(\mathrm{HpzMe}, \mathrm{An})\left(\mathrm{HB}\left\{\mathrm{pzAn}, \mathrm{Me}_{3}\right)\right] \cdot \mathrm{CH}_{2} \mathrm{Cl}_{2}\right.$ and copper compounds $\left[\mathrm{Cu}(\mathrm{OAc})(\mathrm{HpzMe}, \mathrm{An})\left(\mathrm{HB}\{\mathrm{pzAn}, \mathrm{Me}\}_{3}\right)\right] \cdot \mathrm{CH}_{2} \mathrm{Cl}_{2}$ [pzMe, An = 3-(p-anisyl)-5-methylpyrazolyl] with pyrazole and acetate as ligands [16] [17] [18]. A lower frequency, adsorption bands at $2850-2750 \mathrm{~cm}^{-1}$ are present that were assigned to the $\mathrm{C}-\mathrm{H}$ valence vibrations of the benzenetricarboxylate ring and of the methyl and ethylenediamine groups [19]. The large and intense absorption band observed between $1595-1559 \mathrm{~cm}^{-1}$ is the result of valence vibrations for both $\mathrm{C}=\mathrm{C}$ and $\mathrm{C}=\mathrm{O}$ bonds of benzenetricarboxylate. The valence vibration of the $\mathrm{C}=\mathrm{O}$ group is shifted to lower frequency due to hydrogen bonding interactions between oxygen atoms of the anion and the hydrogen atoms of ethylenediamine or of water. Such a behaviour was also observed in some copper complexes derived from pyridine-2-carboxylate and quinoline-2-carboxylate. The absorption band between $1280-1363 \mathrm{~cm}^{-1}$ is due to the stretching and bending vibration of the $\mathrm{C}=\mathrm{C}$ conjugated bond of the aromatic ring.

Table 1. Diamagnetic contributions of atoms or group of atoms in 1.

\begin{tabular}{|c|c|c|}
\hline Atoms & $\begin{array}{c}\chi_{\mathrm{a}} \\
\left(\times 10^{-6} \mathrm{~m}^{3}\right)\end{array}$ & $\begin{array}{l}\text { Totale } \chi_{\mathrm{a}} \\
\left(\times 10^{-6} \mathrm{~m}^{3}\right)\end{array}$ \\
\hline $\mathrm{C}_{\text {arom }}$ & -6.24 & -74.88 \\
\hline $\mathrm{C}_{\text {saturated }}$ & -6.00 & -36.00 \\
\hline $\mathrm{C}=\mathrm{O}$ & -1.70 & -10.20 \\
\hline $\mathrm{O}$ & -3.36 & -20.16 \\
\hline $\mathrm{N}_{\mathrm{amine}}$ & -5.55 & -33.30 \\
\hline $\mathrm{H}$ & -2.93 & -128.92 \\
\hline $\mathrm{H}_{2} \mathrm{O}$ & -13.00 & -91.00 \\
\hline \multicolumn{2}{|c|}{$\Sigma \chi_{\mathrm{a}}=\chi_{\mathrm{Dia}}$} & -427.5 \\
\hline
\end{tabular}

$\mathrm{T}=292 \mathrm{~K}, \mathrm{~m}=0.104 \mathrm{~g}$, length $=15 \mathrm{~mm}$.

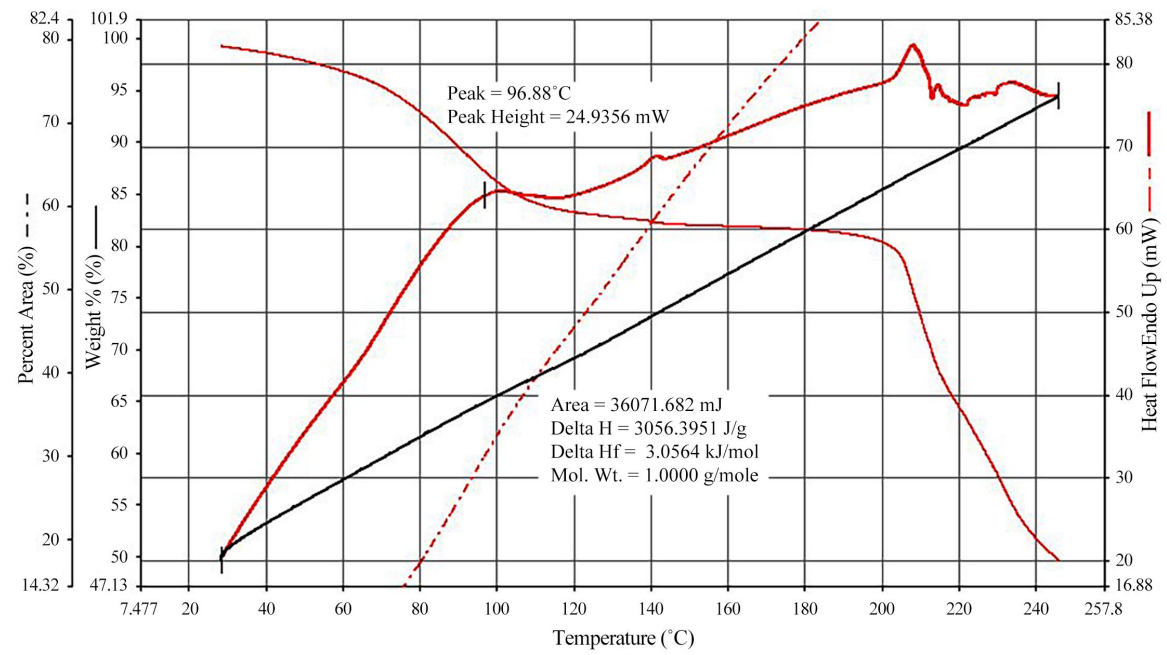

Figure 1. Thermal analysis of compound 1. Light red curve (TGA), dark red curve (heat flow), \% weight (black line), percent area (red dashed line). 


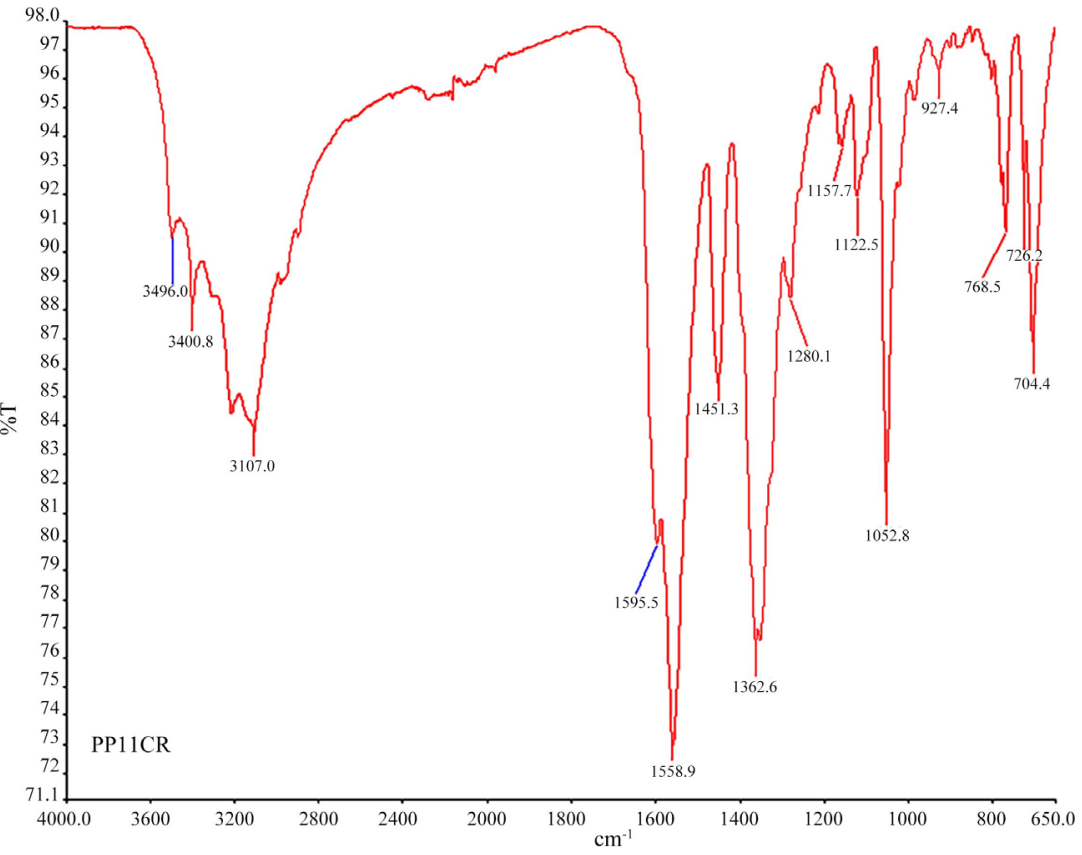

Figure 2. FT-IR spectrum of 1 .

\subsection{UV-Vis Spectroscopy}

UV-vis spectroscopy analysis of 1 (Figure 3 ) showed no absorption band in the visible region expected in the range $350-800 \mathrm{~nm}$. However, the spectrum shows a single absorption band at $296 \mathrm{~nm}$ which is attributed to intraligand $\pi \rightarrow \pi^{*}$ electronic transitions due to $\mathrm{C}=\mathrm{O}, \mathrm{C}=\mathrm{C}$ bonds. The broadness of the band and the absorption peak observed is due to the presence of copper that is covalently bound to oxygen.

\subsection{X-Ray Single Crystal Structure}

Single crystals X-ray diffraction analysis of 1 (Figure 4 and Figure 5, Table 2 and Table 3) showed the formation of a coordination polymer in which the repeating unit is the dimer

$\left\{\left[\mathrm{Cu}_{3}\left(\mu_{3}-1,2,3-\mathrm{BTC}\right)\left(\mu_{2}-1,2,3-\mathrm{BTC}\right)(\mathrm{en})_{3}\left(\mathrm{OH}_{2}\right)_{2}(\mathrm{OH})\left(\mu_{2}-\mathrm{OH}_{2}\right)\right]_{2} \cdot 5 \mathrm{H}_{2} \mathrm{O} \cdot \mathrm{O}\right\}$ that is connected by a $\mathrm{Cu}_{3}-\mathrm{O}_{20}$ interatomic distance of 2.484(5) $\AA$ that is shorter than the van der Waals radii of $\mathrm{Cu}(2.0 \AA)$ and $\mathrm{O}(1.55 \AA)$. The extension into a polymer is then assumed by a $\mu_{2}$-bridging benzene tricarboxylates moiety through a stronger interatomic contacts $\mathrm{Cu} 2-\mathrm{O} 11$ of 1.9776(5) $\AA$ that is significantly shorter than the $\mathrm{Cu}_{3}-\mathrm{O}_{20}$ distance connecting the dimeric unit and slightly longer than the $\mathrm{Cu}_{3}-\mathrm{O}_{2}(1.958(5) \AA)$ bond length.

The copper atoms in the unit cell exhibit different coordination modes. Indeed, $\mathrm{Cu} 1$ is octahedral coordinated by two nitrogen $\left(\mathrm{Cu}_{1}-\mathrm{N}_{3} / \mathrm{N}_{4}=1.999(6) / 2.009710\right)$ $\AA$ ) and four oxygen atoms from the tricarboxylate unit $\left(\mathrm{Cu}_{1}-\mathrm{O}_{4}=1.956(5) \AA\right)$ and from three water molecules $\left(\mathrm{Cu}_{1}-\mathrm{O}_{14} / \mathrm{O}_{18 /} \mathrm{O}_{20}=1.983(5) / 2.484(5) / 2.521(8) \AA\right)$. In contrast, the $\mathrm{Cu}_{2}$ and $\mathrm{Cu}_{3}$ copper atoms have a square pyramidal coordination geometry formed by two nitrogen $\left(\mathrm{Cu} 2-\mathrm{N}_{1} / \mathrm{N}_{2}=1.994(6) / 1.997(6), \mathrm{Cu}_{3}-\mathrm{N}_{5} / \mathrm{N}_{6}=\right.$ 
1.985(6)/1.995(5) $\AA$ ) and three oxygen atoms from the tricarboxylate fragment $\left(\mathrm{Cu}_{2}-\mathrm{O}_{2} / \mathrm{O}_{11}=1.958(5) / 1.9776(5) \AA, \mathrm{Cu}_{3}-\mathrm{O}_{6} / \mathrm{O}_{8}=1.964(4) / 1.958(5) \AA\right)$, from a hydroxyl group $\left(\mathrm{Cu}_{2}-\mathrm{O}_{11}=2.281(6) \AA\right)$ and from a water molecule $\left(\mathrm{Cu}_{3}-\mathrm{O}_{20}=\right.$ 2.484(5) $\AA$ ). While the ethylenediamine is chelating each copper center, the benzene tricarboxylate fragment is triply bonded to three copper atoms in a monodentate manner and establishes a bridge between the repeating unit. The coordination of the 1,2,3-BTC, ethylenediamine and bridging water molecules generates a two-dimensional coordination polymer with $4.33 \times 6.68 \AA^{2}$ quasi-rectangular pores (Figure 6).

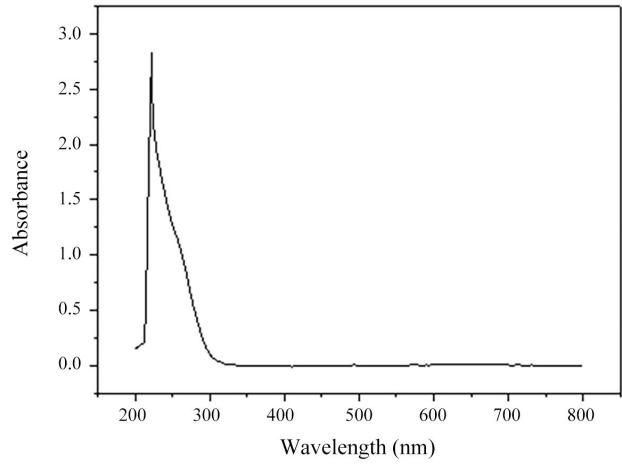

Figure 3. UV-vis spectra of 1 .

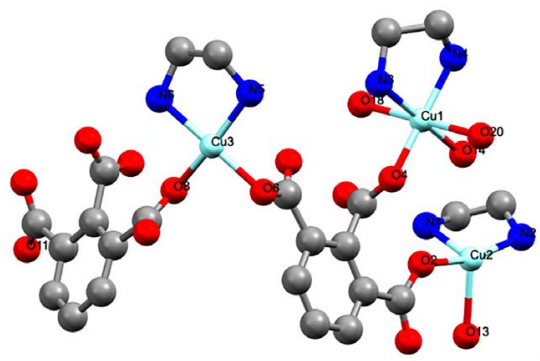

Figure 4. Molecular structure of 1 showing the monomeric unit. The hydrogen and oxygen atoms, and the solvated water molecules were removed for clarity.

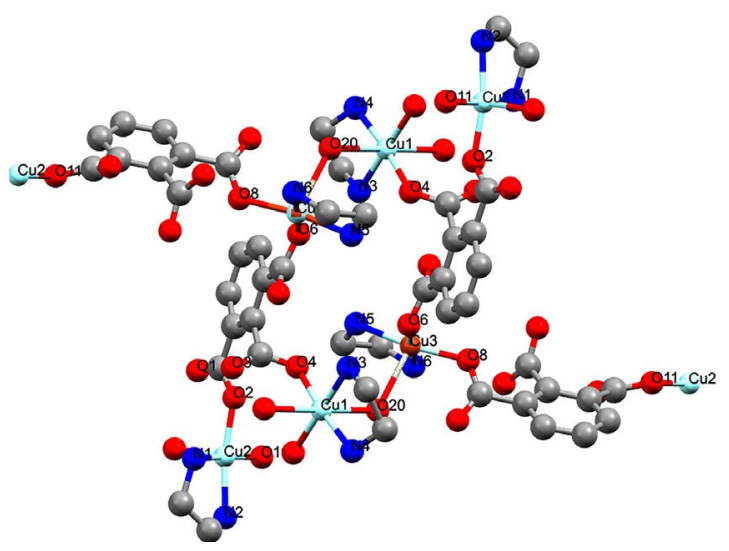

Figure 5. Two-dimensional coordination polymer of 1 showing the interatomic connections. 


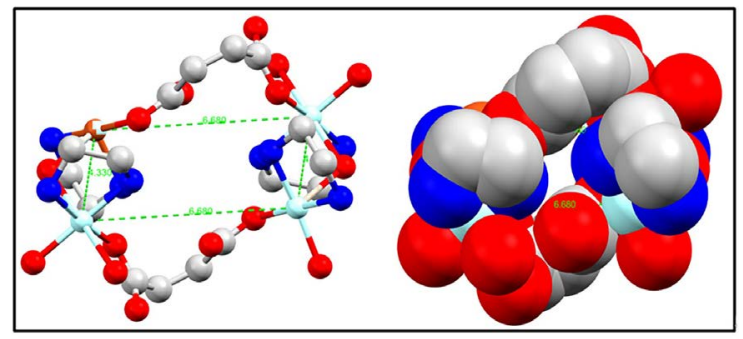

Figure 6. Pores observed in the coordination polymer. (left) ball and stick and (right) Spacefill views.

Table 2. Crystal data and refinement details for $\left\{\left[\mathrm{Cu}_{3}\left(\mu_{3}-1,2,3-\mathrm{BTC}\right)\left(\mu_{2}-1,2,3-\mathrm{BTC}\right)(\mathrm{en})_{3}\left(\mathrm{OH}_{2}\right)_{2}(\mathrm{OH})\left(\mu_{2}-\mathrm{OH}_{2}\right)\right]_{2} \cdot 5 \mathrm{H}_{2} \mathrm{O} \cdot \mathrm{O}\right\}_{\mathrm{n}}(1)$.

\begin{tabular}{|c|c|c|c|}
\hline Compound & & 1 & \\
\hline Empirical formula & $\mathrm{C}_{24} \mathrm{H}_{45} \mathrm{Cu}_{3} \mathrm{~N}_{6} \mathrm{O}_{21}$ & $\rho_{\text {calc }}, \mathrm{g} \cdot \mathrm{cm}^{-3}$ & 1.649 \\
\hline MW & 944.28 & $\mu(\mathrm{Cu} \mathrm{Ka}), \mathrm{mm}^{-1}$ & 1014 \\
\hline$T, \mathrm{~K}$ & 100 & Crystal size, mm & $0.132 \times 0.198 \times 0.265$ \\
\hline Wavelength, $\AA$ & 1.54178 & $\theta$ range, deg & $3.33-52.73$ \\
\hline Crystal system & Triclinic & Limiting indices & $\begin{aligned}-12 & \leq \mathrm{h} \leq 12 \\
-13 & \leq \mathrm{k} \leq 13 \\
-14 & \leq 1 \leq 14\end{aligned}$ \\
\hline Space group & $P-1$ & Reflns collected & 14,230 \\
\hline a, $\AA$ & $12.1205(3)$ & Independent reflns & 4253 \\
\hline$b, \AA$ & $12.7026(3)$ & Absorption correction & Numerical \\
\hline$c, \AA$ & $13.9890(3)$ & Data/restraints/parameters & $\begin{array}{c}4253 / 26 / 479 \\
{[R(\mathrm{int})=0.023]}\end{array}$ \\
\hline$\alpha, \operatorname{deg}$ & $75.034(1)$ & Goodness-of-fit on $F^{2}$ & 1.095 \\
\hline$\beta, \operatorname{deg}$ & $74.957(1)$ & Final $R$ indices, $[\mathrm{I}>2 \sigma(\mathrm{I})]^{[a]}$ & $\begin{array}{c}R 1=0.057 \\
\mathrm{w} R 2=0.149\end{array}$ \\
\hline$\gamma, \operatorname{deg}$ & $68.415(1)$ & $R$ indices (all data) ${ }^{[\mathrm{a}]}$ & 0.059 \\
\hline$V, \AA^{3}$ & $1902.07(8)$ & Peak $_{\max } /$ hole $_{\min }\left(\mathrm{e} \AA^{-3}\right)$ & $2.03-0.708$ \\
\hline$Z$ & 2 & & \\
\hline
\end{tabular}

Table 3. Selected bond distances $(\AA)$ and angles $\left({ }^{\circ}\right)$ for $\left\{\left[\mathrm{Cu}_{3}\left(\mu_{3}-1,2,3-\mathrm{BTC}\right)\left(\mu_{2}-1,2,3-\mathrm{BTC}\right)(\mathrm{en})_{3}\left(\mathrm{OH}_{2}\right)_{2}(\mathrm{OH})\left(\mu_{2}-\mathrm{OH}_{2}\right)\right]_{2} \cdot 5 \mathrm{H}_{2} \mathrm{O} \cdot \mathrm{O}\right\}_{\mathrm{n}}(1)$.

\begin{tabular}{lccc}
\hline Bonds & Lengths $(\AA)$ & Bond angles & $\left({ }^{\circ}\right)$ \\
\hline $\mathrm{Cu}_{1}-\mathrm{O}_{4}$ & $1.956(5)$ & $\mathrm{O}_{4}-\mathrm{Cu}_{1}-\mathrm{O}_{14}$ & $91.08(19)$ \\
$\mathrm{Cu}_{1}-\mathrm{O}_{14}$ & $1.983(5)$ & $\mathrm{O}_{4}-\mathrm{Cu}_{1}-\mathrm{N}_{3}$ & $90.4(2)$ \\
$\mathrm{Cu}_{1}-\mathrm{O}_{18}$ & $2.484(5)$ & $\mathrm{O}_{14}-\mathrm{Cu}_{1}-\mathrm{N}_{3}$ & $177.2(2)$ \\
$\mathrm{Cu}_{1}-\mathrm{O}_{20}$ & $2.521(8)$ & $\mathrm{O}_{4}-\mathrm{Cu}_{1}-\mathrm{N}_{4}$ & $173.72(14)$ \\
$\mathrm{Cu}_{1}-\mathrm{N}_{3}$ & $1.999(6)$ & $\mathrm{O}_{14}-\mathrm{Cu}_{1}-\mathrm{N}_{4}$ & $92.95(4)$ \\
$\mathrm{Cu}_{1}-\mathrm{N}_{4}$ & $2.0097(10)$ & $\mathrm{N}_{3}-\mathrm{Cu}_{1}-\mathrm{N}_{4}$ & $85.72(18)$ \\
$\mathrm{Cu}_{2}-\mathrm{O}_{2}$ & $1.958(5)$ & $\mathrm{O}_{2}-\mathrm{Cu}_{2}-\mathrm{O}_{11}$ & $90.42(19)$ \\
$\mathrm{Cu}_{2}-\mathrm{O}_{11}$ & $1.976(5)$ & $\mathrm{O}_{2}-\mathrm{Cu}_{2}-\mathrm{N}_{1}$ & $90.8(2)$ \\
\hline
\end{tabular}




\section{Continued}

\begin{tabular}{cccc}
\hline $\mathrm{Cu}_{2}-\mathrm{N}_{1}$ & $1.994(6)$ & $\mathrm{O}_{11}-\mathrm{Cu}_{2}-\mathrm{N}_{1}$ & $171.5(2)$ \\
$\mathrm{Cu}_{2}-\mathrm{N}_{2}$ & $1.997(6)$ & $\mathrm{O}_{2}-\mathrm{Cu}_{2}-\mathrm{N}_{2}$ & $165.8(2)$ \\
$\mathrm{Cu}_{2}-\mathrm{O}_{13}$ & $2.281(6)$ & $\mathrm{O}_{11}-\mathrm{Cu}_{2}-\mathrm{N}_{2}$ & $91.5(2)$ \\
$\mathrm{Cu}_{3}-\mathrm{O}_{8}$ & $1.958(5)$ & $\mathrm{N}_{1}-\mathrm{Cu}_{2}-\mathrm{N}_{2}$ & $85.3(3)$ \\
$\mathrm{Cu}_{3}-\mathrm{O} 6$ & $1.964(4)$ & $\mathrm{O}_{2}-\mathrm{Cu}_{2}-\mathrm{O}_{13}$ & $95.2(2)$ \\
$\mathrm{Cu}_{3}-\mathrm{O}_{20}$ & $2.484(5)$ & $\mathrm{O}_{11}-\mathrm{Cu}_{2}-\mathrm{O}_{13}$ & $84.4(2)$ \\
$\mathrm{Cu}_{3}-\mathrm{N}_{5}$ & $1.985(6)$ & $\mathrm{N}_{1}-\mathrm{Cu}_{2}-\mathrm{O}_{13}$ & $103.8(3)$ \\
$\mathrm{Cu}_{3}-\mathrm{N}_{6}$ & $1.995(5)$ & $\mathrm{N}_{2}-\mathrm{Cu}_{2}-\mathrm{O}_{13}$ & $99.0(2)$ \\
& & $\mathrm{O}_{8}-\mathrm{Cu}_{3}-\mathrm{O}_{6}$ & $89.78(19)$ \\
& & $\mathrm{O}_{8}-\mathrm{Cu}_{3}-\mathrm{N}_{5}$ & $169.0(2)$ \\
& & $\mathrm{O}_{-}-\mathrm{Cu}_{3}-\mathrm{N}_{5}$ & $94.7(2)$ \\
& & $\mathrm{O}_{8}-\mathrm{Cu}_{3}-\mathrm{N}_{6}$ & $89.3(2)$ \\
& & $\mathrm{O}_{6}-\mathrm{Cu}_{3}-\mathrm{N}_{6}$ & $178.29(2)$ \\
& & $\mathrm{N}_{5}-\mathrm{Cu}_{3}-\mathrm{N}_{6}$ & $85.9(2)$ \\
\hline
\end{tabular}

\section{Conclusion}

Violet crystals of the copper complex

$\left\{\left[\mathrm{Cu}_{3}\left(\mu_{3}-1,2,3-\mathrm{BTC}\right)\left(\mu_{2}-1,2,3-\mathrm{BTC}\right)(\mathrm{en})_{3}\left(\mathrm{OH}_{2}\right)_{2}(\mathrm{OH})\left(\mu_{2}-\mathrm{OH}_{2}\right)\right]_{2} \cdot 5 \mathrm{H}_{2} \mathrm{O} \cdot \mathrm{O}\right\}_{\mathrm{n}}$ were isolated at ambient temperature and analyzed using various techniques. The determination of the molecular structure by X-ray diffraction analysis showed that the material is made up of quasi-rectangular pores capable of capturing small gaseous molecules. The complex is on the other hand characterized by a polymeric nature through $\mathrm{Cu}-\mathrm{O}$ interatomic interactions. The thermal analysis showed loss of weigh of the compound between $40^{\circ} \mathrm{C}-120^{\circ} \mathrm{C}$ and above $200^{\circ} \mathrm{C}$, while the magnetic susceptibility indicates that the polymer is either ferromagnetic or antiferromagnetic. Futures work will be dedicated to the application of the polymeric hydrid material in nitrogen sorption.

\section{Acknowledgements}

The authors are grateful to Prof Claudio Pettinari of the University of Camerino (Italy) \& Prof Álvarez Eleuterio of the University of Seville (Spain) for spectroscopic, Thermogravimetric analyses and X-Ray facilities. A.C.T.K. is grateful to the World Academic of Science (TWAS) for equipment support (under Grant Ref. 18-017 RG/CHE/AF/AC-1-FR3240303619). This work was partially supported by the "allocation spéciale pour la modernisation de la recherche universitaire" from the Ministry of Higher Education (Cameroon).

\section{Conflicts of Interest}

No potential conflict of interest was reported by the author(s). 


\section{References}

[1] Shimomura, S., Higuchi, M., Matsuda, R., Yoneda, K., Hijikata, Y., Kubota, Y., Mita, Y., Kim, J., Takata, M. and Kitagawa, S. (2010) Selective Sorption of Oxygen and Nitric Oxide by an Electron-Donating Flexible Porous Coordination Polymer. $\mathrm{Na}$ ture Chemistry, 2, 633-637. https://doi.org/10.1038/nchem.684

[2] Kuppler, R.J., Timmons, D.J., Fang, Q.-R., Li, J.R., Makal, T., Young, M.D., Yuan, D., Zhao, D., Zhuang, W. and Zhou, H.C. (2009) Potential Application of Metal-Organic Framework. Coordination Chemistry Reviews, 253, 3042-3066. https://doi.org/10.1016/j.ccr.2009.05.019

[3] Orturk, K., Kose, D.A., Asan, A. and Orturk, B. (2012) A Kind of Energy Storage Technology: Metal-Organic-Frameworks. International Journal of Renewable Energy Research, 2, 44-46.

[4] Gu, Z., Park, J., Raiff, A., Wei, Z. and Zhou, H. (2014) Metal-Organic-Frameworks as Biomimetic Catalysts. Chemical Catalysis Catalytical Chemistry, 6, 67-75. https://doi.org/10.1002/cctc.201300493

[5] Kitaura, R., Kitagawa, S., Kubota, Y., kobayashi, T.C., Kindo, K., Mita, Y., Matsuo, K., Kobayashi, M., Chang, H.C., Ozawa, T.C., Suzuki, M., Sakata, M. and Takata, M. (2002) Formation of a One-Dimension Array of Oxygen in a Microporous Metal-Organic Solid. Sciences, 298, 2358-2361. https://doi.org/10.1126/science.1078481

[6] Kaneko, D. and Li, K. (2000) Molecular Geometry-Sensitive Filling in Semi-Rectangular Micropores of Organic-Inorganic Hybrid Crystals. Journal of Physical Chemistry $B$, 104, 8940-8945. https://doi.org/10.1021/jp000660q

[7] Mason, J.A., Veenstra, M. and Long, J.R. (2014) Evaluating Metal-Organic-Frameworks for Natural Gas Storage. Chemical Science, 5, 32-51.

https://doi.org/10.1039/C3SC52633J

[8] Tahli, A., Elshaarawy, R.F.M., Köc, Ü., Kautz, A.C. and Janiak, C. (2016) A HKUST-1 MOF Inclusion Compound with In-Situ Reduced Copper(I) as [Cu(NCCH3)4 $]^{+}$ Cation Complex in the Octahedral A-Type Pore. Polyhedron, 117, 579-584. https://doi.org/10.1016/j.poly.2016.06.039

[9] Ngoune, J., Corrado, D.N., Nenwa, J., Pettinari, C., Alvarez, E. and Ponou, S. (2013) A Supramolecular Copper(II) Compound with Double Bridging Water Ligands: Synthesis, Crystal Structure, Spectroscopy, Thermal Analysis, and Magnetism. Transition Metal Chemistry, 38, 21-29. https://doi.org/10.1007/s11243-012-9656-6

[10] Bruker (2005) SAINT Version 7.23a. Bruker AXS Inc., Madison.

[11] Bruker (2006) APEX 2 Version 2.0-2. Bruker AXS Inc., Madison.

[12] Sheldrick, G.M. (2008) SADABS. University of Göttingen, Göttingen.

[13] Sheldrick, G.M. (2008) A Short History of SHELX. Acta Crystallographica Section A. Foundations of Crystallography A, 64, 112-122. https://doi.org/10.1107/S0108767307043930

[14] Sheldrick, G.M. (2015) Crystal Structure Refinement with SHELXL. Acta Crystallographica Section C. Structural Chemistry C, 71, 3-8. https://doi.org/10.1107/S2053229614024218

[15] Ghoshal, D., Maji, T.K., Mostafa, G., Sain, S., Lu, T.H., Ribas, J., Zangrando, E. and Chaudhuri, N.R. (2004) Polymeric Networks Copper(II) Using Succinate and Aromatic N-N Donor Ligands: Synthesis, Crystal Structure, Magnetic Behaviour and the Effect of Weak Interactions on Their Crystal Packing. Dalton Transaction, 11, 1687-1695. https://doi.org/10.1039/B401738B

[16] Deng, Y., Wang, R.J., Ding, T.Z., Li, Y., Sun, S.Q., Feng, Y.P. and Zhao, Y.F. (2001) 
Synthesis and Characterization of Cadmium, Copper and Zinc Complexes with Scorpionate Ligand Hydrotris[3-(p-anisyl)-5-methylpyrazol-1-yl]borate[HB\{pzAn,Me\}3]. X-Ray Structure of $[\mathrm{Cd}(\mathrm{OAc})(\mathrm{HpzMe}, \mathrm{An})(\mathrm{HB}\{\mathrm{pzAn}, \mathrm{Me}\} 3)] \cdot \mathrm{CH}_{2} \mathrm{Cl}_{2}$. Polyhedron, 20, 291-295. https://doi.org/10.1016/S0277-5387(00)00626-4

[17] Masciocchi, N., Galli, S., Alberti, E., Sironi, A., Corrado, D.N., Pettinari, C. and Pandolfo L. (2006) Synthesis, Solid-State NMR, and X-Ray Powder Diffraction Characterization of Group 12 Coordination Polymers, Including the First Example of a C-Mercuriated Pyrazole. Inorganic Chemistry, 45, 9064-9074.

https://doi.org/10.1021/ic061349b

[18] Baggio, R., Garland, M.T., Perec, M. and Vega, D. (1999) Adduct Formation between Zinc and Cadmium Oxydiacetates and Imidazole. Crystal Structures of $\left[\mathrm{Zn}(\mathrm{Him})_{2}(\mathrm{oda})\right]_{\mathrm{n}}$ and $\left[\mathrm{Cd}_{2}(\mathrm{Him})_{4}(\mathrm{oda})_{2}\left(\mathrm{H}_{2} \mathrm{O}\right)\right]_{2} \cdot 6 \mathrm{H}_{2} \mathrm{O}(\mathrm{Him}=$ Imidazole, Oda $=$ Oxydiacetate). Inorganica Chimica Acta, 284, 49-54.

https://doi.org/10.1016/S0020-1693(98)00274-6

[19] Masciocchi, N., Pettinari, C., Alberti, E., Pettinari, R., Corrado, D.N., Albisetti, A.F. and Sironi, A. (2007) Structural and Thermodiffractometric Analysis of Coordination Polymers. Part II: 1 Zinc and Cadmium Derivatives of the Bim Ligand Bim[bis(1-imidazolyl)methane]. Inorganic Chemistry, 46, 10501-10509.

https://doi.org/10.1021/ic7015319 